\title{
2-(2-Phenylethyl)-4H-chromen-4-one Derivatives from the Resinous Wood of Aquilaria sinensis with Anti-Inflammatory Effects in LPS-Induced Macrophages
}

\author{
Sin-Ling Wang ${ }^{1}$, Yun-Chen Tsai ${ }^{2}$, Shu-Ling Fu ${ }^{2,+}$, Ming-Jen Cheng ${ }^{3}$, Mei-Ing Chung ${ }^{1, *, \dagger}$ \\ and Jih-Jung Chen ${ }^{4,5, *}$ \\ 1 School of Pharmacy, College of Pharmacy, Kaohsiung Medical University, Kaohsiung 807, Taiwan; \\ s8332805@yahoo.com.tw \\ 2 Institute of Traditional Medicine, National Yang-Ming University, Taipei 112, Taiwan; \\ tyc202006@gmail.com (Y.-C.T.); slfu@ym.edu.tw (S.-L.F.) \\ 3 Bioresource Collection and Research Center (BCRC), Food Industry Research and Development Institute \\ (FIRDI), Hsinchu 300, Taiwan; cmj@firdi.org.tw \\ 4 Faculty of Pharmacy, School of Pharmaceutical Sciences, National Yang-Ming University, Taipei 112, Taiwan \\ 5 Department of Medical Research, China Medical University Hospital, China Medical University, \\ Taichung 404, Taiwan \\ * Correspondence: meinch@kmu.edu.tw (M.-I.C.); chenjj@ym.edu.tw (J.-J.C.); \\ Tel.: +886-7-312-1101 (ext. 2672) (M.-I.C.); +886-2-2826-7195 (J.-J.C.) \\ + These authors contributed equally to this work.
}

Received: 6 January 2018; Accepted: 27 January 2018; Published: 30 January 2018

\begin{abstract}
The resinous wood of Aquilaria sinensis, known as agarwood (Chen Xiang in Chinese), is traditionally used for the treatment of abdominal pain, vomiting, circulatory disorders, and dyspnea. Four new 2-(2-phenylethyl)-4H-chromen-4-one derivatives, namely 7-methoxy-2-[2-(4'-hydroxyphenyl)ethyl]chromone (1), 7-hydroxy-2-[2-(4'-methoxyphenyl)ethyl]chromone (2), 5,6-dihydroxy2-[2-(3'-hydroxy-4'-methoxyphenyl)ethyl]chromone (3), and 6-hydroxy-5-methoxy-2-(2-phenylethyl)chromone (4), have been isolated from the resinous wood of $A$. sinensis, together with nine known compounds. The structures of these compounds were determined through spectroscopic and MS analyses. Among the isolated compounds, neopetasan, 7-methoxy-2-(2-phenylethyl)chromone, 6,7-dimethoxy-2-(2-phenylethyl)chromone, and 6,7-dimethoxy-2-[2-(4'-methoxyphenyl)ethyl]chromone inhibited NF-kB activation in LPS-stimulated RAW 264.7 macrophages with relative luciferase activity values of $0.55 \pm 0.09,0.54 \pm 0.03,0.31 \pm 0.05$, and $0.38 \pm 0.14$, respectively, versus that of vehicle control (1.03 \pm 0.02$)$. In addition, 5,6-dihydroxy-2-[2-(3'-hydroxy4'-methoxyphenyl)ethyl]chromone, 7-methoxy-2-(2-phenylethyl)chromone, 7-dimethoxy-2-(2phenylethyl)chromone, and 6,7-dimethoxy-2-[2-(4'-methoxyphenyl)ethyl]chromone could suppress LPS-induced NO production in RAW 264.7 cells and did not induce cytotoxicity against RAW 264.7 cells after 24-h treatment.
\end{abstract}

Keywords: Aquilaria sinensis; Thymelaeaceae; resinous wood; structure elucidation; 2-(2-phenylethyl)$4 H$-chromen-4-one; anti-inflammatory activity

\section{Introduction}

Aquilaria sinensis (Lour.) Gilg. (Thymelaeaceae) is an evergreen tree endemic to China. The fragrant resin-infused wood derived from the wounded trees of Aquilaria species is called 'agarwood' or 'eaglewood'. Agarwood has been widely used as a traditional sedative, analgesic, and digestive 
medicine in China [1]. Various benzenoids [2], flavonoids [2,3], 2-(2-phenylethyl)chromones [2,4-7], sesquiterpenes [8], steroids [2,7], triterpenoids [5], and their derivatives were isolated from this plant in previous studies. Many of these compounds exhibit anti-acetylcholinesterase [8], anti-inflammatory [2,7], antitumor [3], and cytotoxic [6] activities.

Aberrant activation of macrophages is related to many inflammatory disorders such as sepsis, neurodegenerative disorders, osteoporosis, cardiovascular and metabolic diseases [9]. Nuclear factor $\mathrm{KB}(\mathrm{NF}-\mathrm{KB})$ is an important transcription factor when stimulating an inflammatory reaction and as a molecular target for anti-inflammatory drug discovery. Lipopolysaccharide (LPS)-stimulated macrophages have been prevalently applied as an in vitro model system to study inflammation and to identify anti-inflammatory compounds $[10,11]$. In our studies on the anti-inflammatory constituents of Formosan plants and Chinese herbal medicines, many species have been screened for in vitro inhibitory activity against NF- $\mathrm{KB}$, a key transcriptional activator of pro-inflammatory molecules in LPS-activated macrophages, and A. sinensis was found to be an active species. Four new 2-(2-phenylethyl)-4H-chromen-4-one derivatives, namely 7-methoxy-2-[2-(4'-hydroxyphenyl)ethyl]chromone (1), 7-hydroxy-2-[2-(4'-methoxyphenyl)ethyl]chromone (2), 5,6-dihydroxy-2-[2-(3'hydroxy-4'-methoxyphenyl)ethyl]chromone (3), and 6-hydroxy-5-methoxy-2-(2-phenylethyl)chromone (4), and nine known compounds 5-13 have been isolated from the resinous wood of A. sinensis and identified. Their structures are depicted in Figure 1. This paper describes the structural elucidation of the compounds numbered 1 through 4 and the inhibitory activities of all isolates on LPS-induced NF-kB activation of macrophages.

\section{Results and Discussion}

\subsection{Isolation and Structural Elucidation}

Chromatographic purification of the EtOAc-soluble fraction of a MeOH extract of resinous wood of $A$. sinensis on a silica gel column and preparative thin-layer chromatography (TLC) afforded four new (1-4) and nine known compounds (5-13) (Figure 1).<smiles>COc1ccc2c(=O)cc(CCc3ccc(O)cc3)oc2c1</smiles><smiles>COc1ccc(CCc2cc(=O)c3ccc(O)cc3o2)cc1</smiles><smiles>COc1ccc(CCc2cc(=O)c3c(O)c(O)ccc3o2)cc1O</smiles><smiles>COc1c(O)ccc2oc(CCc3ccccc3)cc(=O)c12</smiles><smiles>C=C(C)C1CC2(C)C(=CC1=O)CCCC2C</smiles><smiles>CC1CCCC2=CC(=O)C(C3(C)CO3)C[C@@]21C</smiles>

5 6

Figure 1. Cont. 
<smiles>CC(C)=C1C[C@]2(C)C(=CC1=O)CCC[C@H]2C</smiles><smiles>[R]c1ccc(CCc2cc(=O)c3cc([R4])c([R])cc3o2)cc1</smiles><smiles>C[C@H]1CCCC2=CC(=O)[C@H](C(C)(C)O)C[C@@]21C</smiles>

8

Figure 1. The chemical structures of compounds 1-13 isolated from A. sinensis.

Compound 1 was obtained as brown plates. The molecular formula, $\mathrm{C}_{18} \mathrm{H}_{16} \mathrm{O}_{4}$, was deduced from a proton adduct ion at $m / z 297.11224[\mathrm{M}+\mathrm{H}]^{+}($calcd. 229.11214) in the HR-ESI-MS spectrum (positive-ion mode) and was supported by the ${ }^{1} \mathrm{H}-,{ }^{13} \mathrm{C}-$, and DEPT NMR data. IR absorptions for $\mathrm{OH}$ $\left(3418 \mathrm{~cm}^{-1}\right)$ and $\gamma$-pyrone (1634 and $\left.1590 \mathrm{~cm}^{-1}\right)$ functions were observed. The ${ }^{1} \mathrm{H}-\mathrm{NMR}$ spectrum of 1 showed the presence of a methoxy group at $\delta_{\mathrm{H}} 3.91(3 \mathrm{H}, \mathrm{s}, \mathrm{MeO}-7)$, four methylene protons at $\delta_{\mathrm{H}} 2.86\left(2 \mathrm{H}, \mathrm{t}, J=8.0 \mathrm{~Hz}, \mathrm{H}-8^{\prime}\right)$ and $2.98\left(2 \mathrm{H}, \mathrm{t}, J=8.0 \mathrm{~Hz}, \mathrm{H}^{\prime} 7^{\prime}\right)$ and a olefinic proton at $\delta_{\mathrm{H}} 6.07$ $(1 \mathrm{H}, \mathrm{s}, \mathrm{H}-3)$. Additionally a set of typical ABX coupling systems at $\delta_{\mathrm{H}} 6.83(1 \mathrm{H}, \mathrm{d}, J=2.0 \mathrm{~Hz}, \mathrm{H}-8)$, $6.95(1 \mathrm{H}, \mathrm{dd}, J=8.5,2.0 \mathrm{~Hz}, \mathrm{H}-6)$ and $8.08(1 \mathrm{H}, \mathrm{d}, J=8.5 \mathrm{~Hz}, \mathrm{H}-5)$ and para-disubstituted benzene protons at $\delta_{\mathrm{H}} 6.76\left(2 \mathrm{H}, \mathrm{d}, J=8.5 \mathrm{~Hz}, \mathrm{H}-3^{\prime}\right.$ and $\left.\mathrm{H}-5^{\prime}\right)$ and $\delta_{\mathrm{H}} 7.06\left(2 \mathrm{H}, \mathrm{d}, J=8.5 \mathrm{~Hz}, \mathrm{H}-2^{\prime}\right.$ and $\left.\mathrm{H}-6^{\prime}\right)$ were observed. The ${ }^{13} \mathrm{C}$-NMR spectrum of 1 displayed the presence of two methylene groups at $\delta_{C} 32.0$ and 36.3 , a trisubstituted double bond at $\delta_{C} 109.8$ and 168.5 , a methoxyl group at $\delta_{C} 56.1$, and a carbonyl group at $\delta_{C} 177.9$. Based on the above, 1 was deduced to be a 2-(2-phenylethyl)chromone derivative with a methoxyl and a hydroxyl groups. Two signals at $\delta_{C} 164.1$ and 154.5 arising from $O$-bearing aromatic $C$-atoms were attributable to $C-7$ and $C-4^{\prime}$ respectively, by related HMBC and comparison with a structurally similar compound $\mathbf{1 0}$. The HMBC correlations (Figure 2) observed between OMe-7 $\left(\delta_{\mathrm{H}} 3.91\right)$ and C-7 $\left(\delta_{\mathrm{C}} 164.1\right)$, as well as NOESY correlations (Figure 2$)$ observed between OMe-7 $\left(\delta_{\mathrm{H}} 3.91\right)$ and $\mathrm{H}-8\left(\delta_{\mathrm{H}} 6.83\right)$ and $\mathrm{H}-6\left(\delta_{\mathrm{H}} 6.95\right)$, revealed that the methoxyl group was supposed to be positioned at C-7. Thus, the hydroxyl group should be linked to the last open position at C- $4^{\prime}$. Consequently, the structure of $\mathbf{1}$ was determined to be 7-methoxy-2-[2-(4'-hydroxyphenyl)ethyl]chromone.
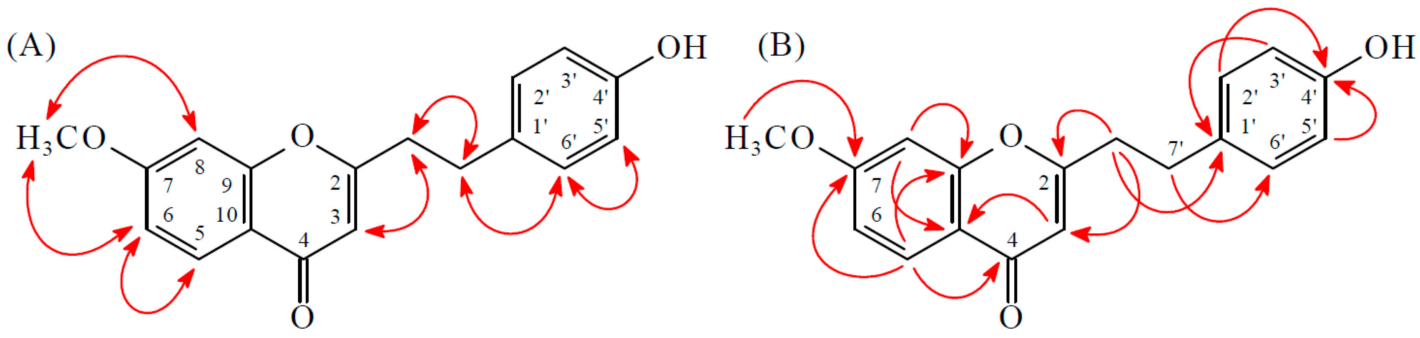

Figure 2. Key NOESY (A) and HMBC (B) correlations of $\mathbf{1}$.

Compound 2 was isolated as a yellowish amorphous powder. The ESI-MS afford the quasi-molecular ion $[\mathrm{M}+\mathrm{H}]^{+}$at $m / z 297$, implying a molecular formula of $\mathrm{C}_{18} \mathrm{H}_{17} \mathrm{O}_{4}$, which was confirmed by the HR-ESI-MS $\left(m / z 297.11227[\mathrm{M}+\mathrm{H}]^{+}\right.$, calcd. 297.11214). The IR spectrum showed the presence of $\mathrm{OH}\left(3210 \mathrm{~cm}^{-1}\right)$ and $\gamma$-pyrone $\left(1635\right.$ and $\left.1600 \mathrm{~cm}^{-1}\right)$ groups. The ${ }^{1} \mathrm{H}$ - and ${ }^{13} \mathrm{C}-\mathrm{NMR}$ data of 2 were similar to those of 7-methoxy-2-[2-(4'-hydroxyphenyl)ethyl]chromone (1), except that the 
$7-\mathrm{OH}$ and $4^{\prime}-\mathrm{OMe}\left[\delta_{\mathrm{H}} 3.79(3 \mathrm{H}, \mathrm{s})\right]$ groups of 2 replaced the $7-\mathrm{OMe}$ and $4^{\prime}-\mathrm{OH}$ groups of $\mathbf{1}$. This was supported by NOESY correlations between OMe $-4^{\prime}\left(\delta_{\mathrm{H}} 3.79\right) / \mathrm{H}-3^{\prime}\left(\delta_{\mathrm{H}} 6.83\right)$ and OMe- $4^{\prime}\left(\delta_{\mathrm{H}} 3.79\right) / \mathrm{H}-5^{\prime}$ $\left(\delta_{\mathrm{H}} 6.83\right)$ and by HMBC correlations between OMe- $4^{\prime}\left(\delta_{\mathrm{H}} 3.79\right) / \mathrm{C}-4^{\prime}\left(\delta_{\mathrm{C}} 158.3\right), \mathrm{H}-5\left(\delta_{\mathrm{H}} 8.02\right) / \mathrm{C}-7$ $\left(\delta_{\mathrm{C}} 156.1\right)$, and H-6 $\left(\delta_{\mathrm{H}} 7.09\right) / \mathrm{C}-7\left(\delta_{\mathrm{C}} 156.1\right)$. According to the above data, the structure of 2 was elucidated as 7-hydroxy-2-[2-(4'-methoxyphenyl)ethyl]chromone. This was further confirmed by the ${ }^{1} \mathrm{H}-{ }^{1} \mathrm{H}-\mathrm{COSY}$, NOESY (Figure 3), DEPT, HSQC, and HMBC (Figure 3) techniques.
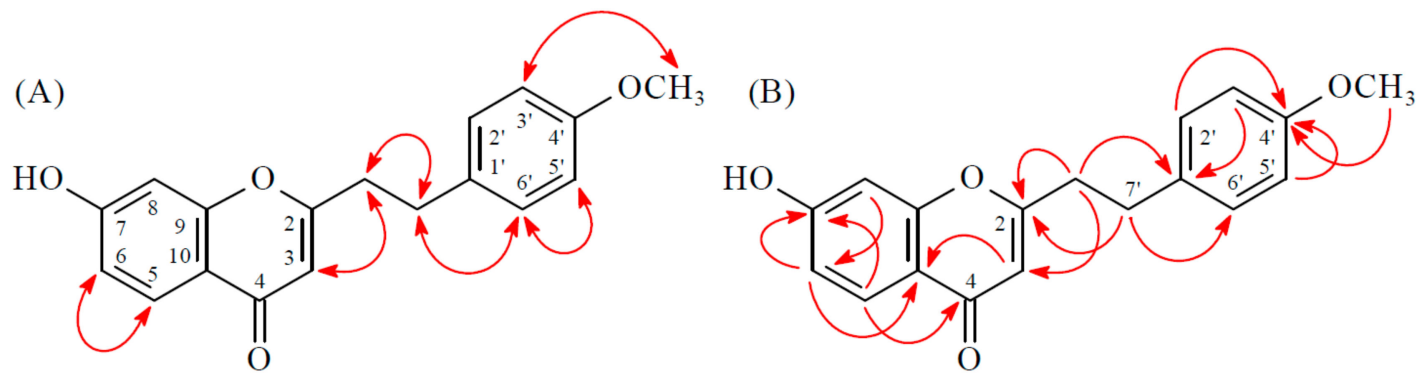

Figure 3. Key NOESY (A) and HMBC (B) correlations of 2.

Compound 3 was isolated as a yellowish amorphous powder. Its molecular formula, $\mathrm{C}_{18} \mathrm{H}_{16} \mathrm{O}_{6}$, was determined on the basis of the positive HRESIMS at $m / z 329.10186[\mathrm{M}+\mathrm{H}]^{+}(\mathrm{calcd}$. 329.10196) and this was supported by the ${ }^{1} \mathrm{H},{ }^{13} \mathrm{C}$, and DEPT NMR data. The IR spectrum showed the presence of $\mathrm{OH}\left(3418 \mathrm{~cm}^{-1}\right)$ and $\gamma$-pyrone $\left(1634\right.$ and $\left.1590 \mathrm{~cm}^{-1}\right)$ groups. The ${ }^{1} \mathrm{H}$ - and ${ }^{13} \mathrm{C}-\mathrm{NMR}$ data of 3 were similar to those of $3^{\prime}, 6$-dihydroxy-4'-methoxy-2-(2-phenylethyl)chromone [7], except that the 5-hydroxy group $\left[\delta_{\mathrm{H}} 12.50\left(1 \mathrm{H}, \mathrm{s}, \mathrm{D}_{2} \mathrm{O}\right.\right.$ exchangeable)] of 3 replaced $\mathrm{H}-5$ of $3^{\prime}, 6$-dihydroxy$4^{\prime}$-methoxy-2-(2-phenylethyl)chromone [7]. This was supported by HMBC correlations between OH-5 $\left(\delta_{\mathrm{H}} 12.50\right)$ and $\mathrm{C}-5\left(\delta_{\mathrm{C}} 145.3\right), \mathrm{C}-6\left(\delta_{\mathrm{C}} 140.2\right)$, and C-10 $\left(\delta_{\mathrm{C}} 111.0\right)$. The full assignment of ${ }^{1} \mathrm{H}-$ and ${ }^{13} \mathrm{C}-\mathrm{NMR}$ resonances was supported by ${ }^{1} \mathrm{H}-{ }^{1} \mathrm{H}$ COSY, DEPT, HSQC, NOESY (Figure 4), and HMBC (Figure 4) spectral analyses. On the basis of the above data, the structure of $\mathbf{3}$ was elucidated as 5,6-dihydroxy-2-[2-(3'-hydroxy-4'-methoxyphenyl)ethyl]chromone.

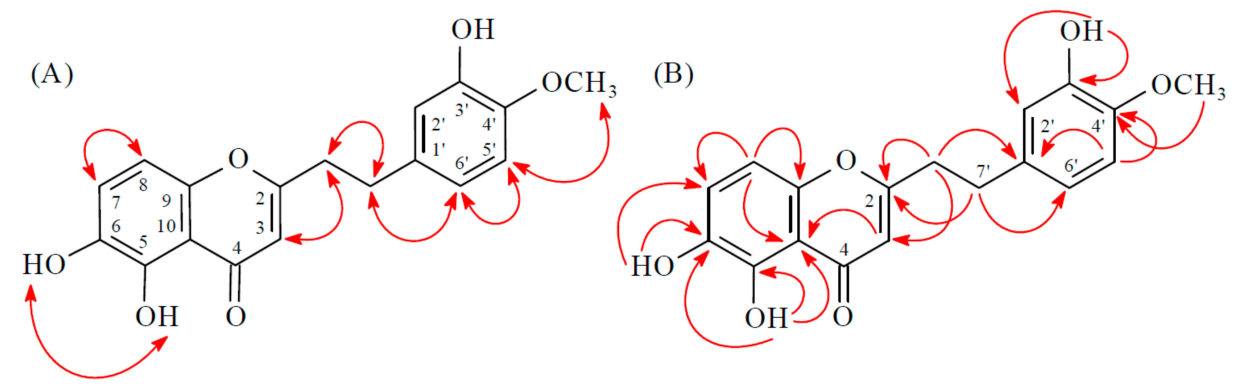

Figure 4. Key NOESY (A) and HMBC (B) correlations of 3.

Compound 4 was obtained as a yellowish amorphous powder. The molecular formula $\mathrm{C}_{18} \mathrm{H}_{16} \mathrm{O}_{4}$ was deduced from a sodium adduct ion at $m / z 319.09395[\mathrm{M}+\mathrm{Na}]^{+}$(calcd. 319.09408) in the HRESI mass spectrum. The presence of a conjugated carbonyl group was revealed by the band at $1633 \mathrm{~cm}^{-1}$ in the IR spectrum, which was confirmed by the resonances at $\delta_{C} 177.5$ in the ${ }^{13} \mathrm{C}-\mathrm{NMR}$ spectrum. The IR spectrum also revealed a hydroxy absorption at $3340 \mathrm{~cm}^{-1}$. Comparison of the ${ }^{1} \mathrm{H}$ - and ${ }^{13} \mathrm{C}-\mathrm{NMR}$ data of 4 with those of 6-hydroxy-2-(2-phenylethyl)chromone (corylifol A) [12] suggested that their structures are closely related, except that the 5-methoxy group $\left[\delta_{\mathrm{H}} 3.98(3 \mathrm{H}, \mathrm{s}) ; \delta_{\mathrm{C}} 62.8\right]$ of 4 replaced H-5 of 6-hydroxy-2-(2-phenylethyl)chromone [12]. This was supported by HMBC correlation between OMe-5 $\left(\delta_{\mathrm{H}} 3.98\right)$ and C-5 $\left(\delta_{\mathrm{C}} 143.5\right)$. The structure elucidation of 4 was supported by ${ }^{1} \mathrm{H}-{ }^{1} \mathrm{H}$ COSY and NOESY (Figure 5) experiments, and ${ }^{13} \mathrm{C}-\mathrm{NMR}$ assignments were confirmed by DEPT, HSQC, and HMBC (Figure 5) techniques. 

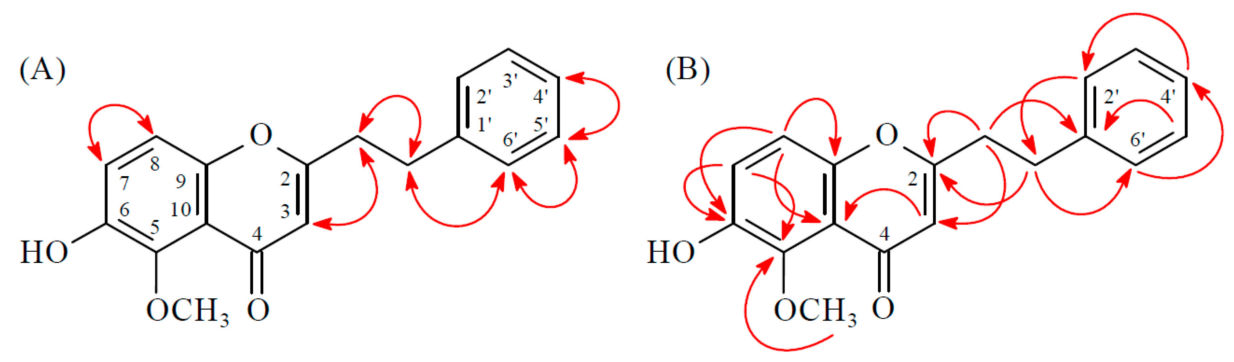

Figure 5. Key NOESY (A) and HMBC (B) correlations of 4.

\subsection{Structure Identification of the Known Isolates}

The known isolates were readily identified by a comparison of physical and spectroscopic data $\left(\mathrm{UV}, \mathrm{IR},{ }^{1} \mathrm{H}-\mathrm{NMR},[\alpha]_{\mathrm{D}}\right.$, and MS) with corresponding authentic samples or literature values, and this included four sesquiterpenes, neopetasane (5) [13], 7 $\alpha-H$-9(10)-ene-11,12-epoxy-8-oxoeremphilane (6) [13], dehydrokaranone (7) [5], and ligudicin C (8) [14], and five 2-(2-phenylethyl)-4H-chromen-4-one derivatives, 2-(2-phenylethyl)chromone (9) [15], 7-methoxy-2-(2-phenylethyl)chromone (10) [16], 6,7-dimethoxy-2-(2-phenylethyl)chromone (11) [2], 6,7-dimethoxy-2-[2-(4'-methoxyphenyl)ethyl]chromone (12) [17], and 6-hydroxy-7-methoxy-2-(2-phenylethyl)chromone (13) [18].

\subsection{Biological Studies}

LPS-activated macrophage serves as an in vitro model system to study inflammation [19]. A LPS-responsive macrophage cell clone RAW264.7/Luc-P1 was previously established, in which the activity of NF-KB correlates with the expression of reporter gene (luciferase) [10]. This RAW 264.7/Luc-P1 cell line has been successfully applied to identify anti-inflammatory compounds [10,19]. Furthermore, LPS-mediated NF- $\mathrm{KB}$ activation leads to upregulation of pro-inflammatory molecules, such as NO, in macrophages [20]. Thus, NO production is a hallmark of inflammatory responses. The anti-inflammatory activities of compounds isolated from the resinous wood of $A$. sinensis were evaluated by their abilities to suppress NF- KB activation in RAW 264.7/Luc-P1 cell line, their inhibitory activities are summarized in Table 1. Andrographolide was used as positive control. Based on the results of our bioactivity assays, the following conclusions can be drawn: (a) 5,6-Dihydroxy-2chromone (3), neopetasane (5), 7 $\alpha-H$-9(10)-ene-11,12-epoxy-8-oxoeremphilane (6), dehydrokaranone (7), 7-methoxy-2-(2-phenylethyl)chromone (10), 6,7-dimethoxy-2-(2-phenylethyl)chromone (11), and 6,7-dimethoxy-2-[2-(4'-methoxyphenyl)ethyl]chro-mone (12) can significantly inhibit LPS-induced NF-kB activation and did not show cytotoxicity against RAW 264.7/Luc-P1 cells after $24 \mathrm{~h}$ treatment (except compound 6 with dose-dependent cytotoxicity in RAW 264.7/Luc-P1 cells) (Figures 6A,C and 7A,C); (b) among the chromone derivatives, 5,6-dihydroxy-2-[2-( $3^{\prime}$-hydroxy$4^{\prime}$-methoxyphenyl)ethyl]chromone (3), 7-methoxy-2-(2-phenylethyl)chromone (10), 7-dimethoxy-2(2-phenylethyl)chromone (11), and 6,7-dimethoxy-2-[2-(4'-methoxyphenyl)ethyl]chromone (12) could suppress LPS-induced NO production in RAW264.7 macrophages (Figure 6B) and did not induce cytotoxicity against RAW 264.7 cells after 24-h treatment (Figure 6D); (c) among the sesquiterpene analogues, neopetasan (5), 7 $\alpha-H$-9(10)-ene-11,12-epoxy-8-oxoeremphilane (6), dehydrokaranone (7) displayed no inhibitory activity on NO production in RAW264.7 macrophages (Figure 7B) and did not cause significant cytotoxicity (Figure 7D); (d) 6,7-dimethoxy-2-(2-phenylethyl)chromone (11) (with a 6-methoxy moiety) exhibited stronger inhibition than its analogue, 6-hydroxy-7-methoxy2-(2-phenylethyl)chromone (13) (with a 6-hydroxy group); (e) 7-methoxy-2-(2-phenylethyl)chromone (10) (without the $4^{\prime}$-hydroxy moiety) exhibited more effective inhibition than its analogue, 7-methoxy-2-[2-(4'-hydroxyphenyl)ethyl]chromone (1) (with a 4'-hydroxy group); (f) 2-(2-phenylethyl) chromone (9) (without any substituents) exhibited no inhibitory activity; (g) among the sesquiterpene analogues 5, 6, and 8, neopetasane (5) (with a prop-1-en-2-yl moiety at C-7) exhibited stronger inhibition than the analogues 6 and 8; (h) 6,7-dimethoxy-2-(2-phenylethyl)chromone (11) was the 
most effective among the isolated compounds, with a relative luciferase activity value of $0.31 \pm 0.05$, against LPS-induced NF-kB activation in RAW 264.7/Luc-P1 cells.

Table 1. The effects of compounds 1-13 from the resinous wood of $A$. sinensis on NF- $\mathrm{KB}$ activation in RAW 264.7/Luc-P1 cells.

\begin{tabular}{cc}
\hline Compounds $^{\text {a }}$ & Relative Luciferase Activity \\
\cline { 2 - 2 } & Mean \pm SD $^{\mathbf{c}}$ \\
\hline 1 & $0.89 \pm 0.05$ \\
2 & $0.93 \pm 0.06$ \\
4 & $0.74 \pm 0.03^{*}$ \\
5 & $0.92 \pm 0.01$ \\
6 & $0.55 \pm 0.09^{*}$ \\
7 & $0.75 \pm 0.05^{*}$ \\
8 & $0.72 \pm 0.16^{*}$ \\
9 & $0.98 \pm 0.07$ \\
10 & $1.26 \pm 0.40$ \\
11 & $0.54 \pm 0.03^{*}$ \\
12 & $0.31 \pm 0.05^{*}$ \\
13 & $0.38 \pm 0.14^{*}$ \\
\hline LPS-treated vehicle control $^{\mathrm{b}}$ & $1.09 \pm 0.21$ \\
\hline Andrographolide & $1.03 \pm 0.02$ \\
\hline
\end{tabular}

a Compounds 1-13: $30 \mu \mathrm{M}$. ${ }^{\mathrm{b}}$ Vehicle control: $0.1 \%$ DMSO. ${ }^{\mathrm{c}}$ Data are expressed as the mean \pm SD from three independent experiments. ${ }^{*}$ indicates significant difference versus LPS $(1 \mu \mathrm{g} / \mathrm{mL})$-treated vehicle control $(p<0.05)$. ${ }^{\mathrm{d}}$ Andrographolide $(30 \mu \mathrm{M})$ is the positive control.

(A)
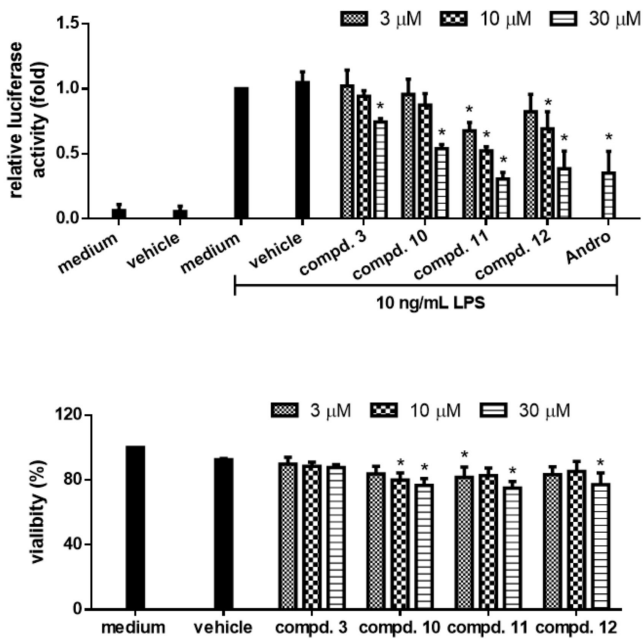

(B)

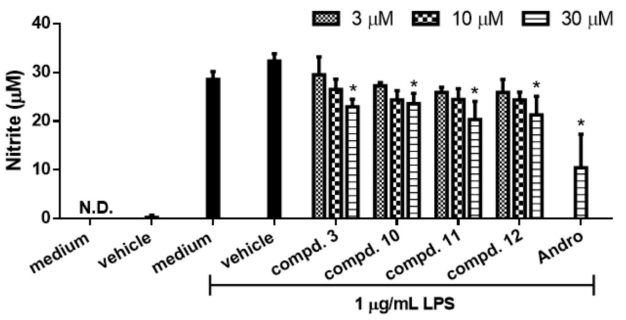

(D)

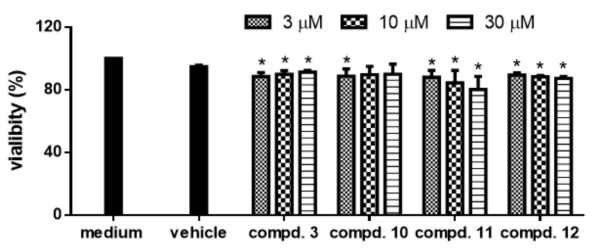

Figure 6. The anti-inflammatory effects of chromone derivatives $\mathbf{3}$ and 10-12 on LPS-stimulated macrophages. (A) RAW264.7/Luc-P1 macrophages $\left(1.5 \times 10^{5}\right.$ cells in 24-well plates) were treated with indicated chromone derivatives or $0.1 \%$ DMSO for $1 \mathrm{~h}$, followed by LPS $(1 \mu \mathrm{g} / \mathrm{mL})$ treatment for $23 \mathrm{~h}$. The luciferase activity of treated groups was measured; (B) RAW 264.7 macrophages $\left(4 \times 10^{4}\right.$ cells in 96 -well plates) were treated with indicated compounds or $0.1 \%$ DMSO for $1 \mathrm{~h}$, followed by LPS $(1 \mu \mathrm{g} / \mathrm{mL})$ treatment $23 \mathrm{~h}$. Culture supernatants were measured for the production of NO using Griess assays. Andro (andrographolide) is the positive control. Data are expressed as the mean $\pm \mathrm{SD}$ from three independent experiments. Asterisk $\left(^{*}\right)$ indicates significant difference versus LPS-treated vehicle control $(p<0.05)$. The cell viability of RAW $264.7 /$ Luc-P1 cells $\left(1 \times 10^{4}\right.$ cells in 96 -well plates $)(C)$ and RAW 264.7 cells $\left(1 \times 10^{4}\right.$ cells in 96-well plates) (D) incubated with chromone derivatives for $24 \mathrm{~h}$ was measured using MTT assay. Data are expressed as the mean \pm SD from three independent experiments. Asterisk $\left(^{*}\right)$ indicates significant difference versus vehicle control $(p<0.05)$. 
(A)

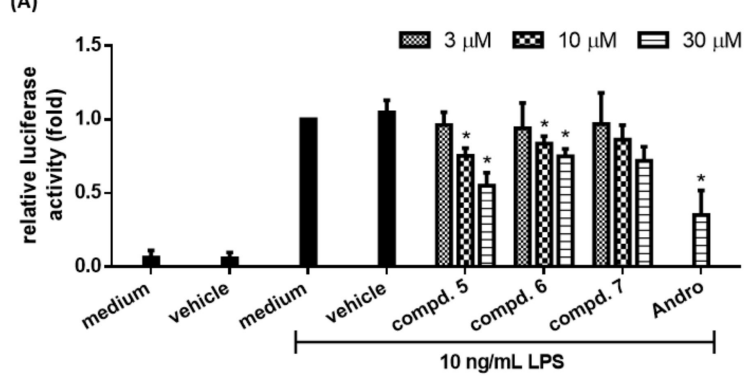

(C)

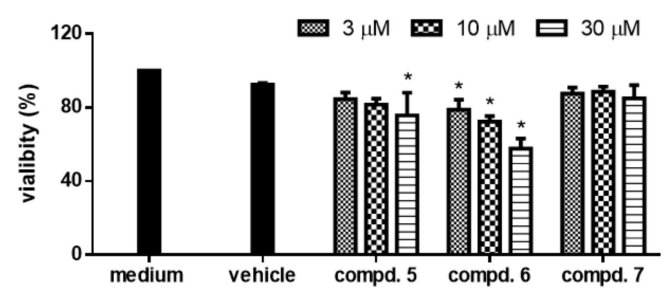

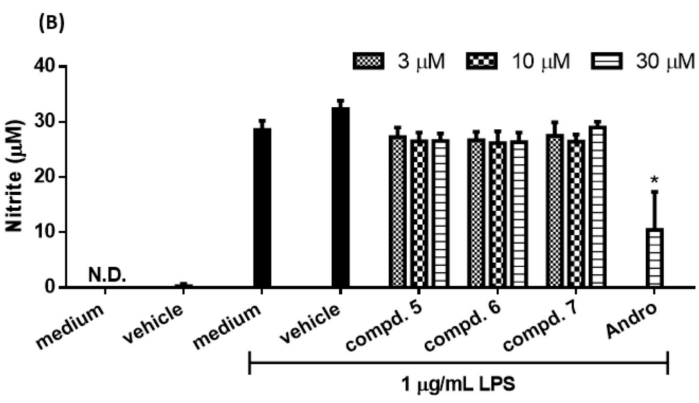

(D)

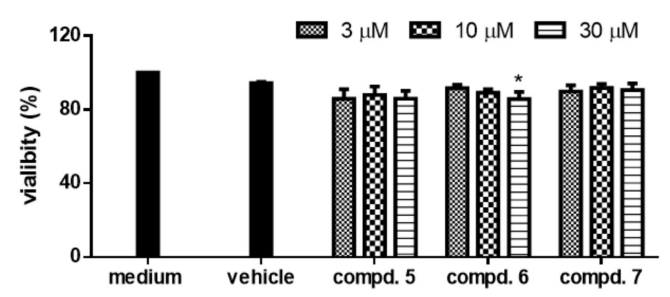

Figure 7. The anti-inflammatory effects of sesquiterpene analogues 5-7 on LPS-stimulated macrophages. (A) RAW264.7/Luc-P1 macrophages $\left(1.5 \times 10^{5}\right.$ cells in 24-well plates) were treated with indicated sesquiterpenes analogs or $0.1 \%$ DMSO for $1 \mathrm{~h}$, followed by LPS $(1 \mu \mathrm{g} / \mathrm{mL})$ treatment for $23 \mathrm{~h}$. The luciferase activity of treated groups was measured; (B) RAW 264.7 macrophages $\left(4 \times 10^{4}\right.$ cells in 96-well plates) were treated with indicated compounds or $0.1 \%$ DMSO for $1 \mathrm{~h}$, followed by LPS $(1 \mu \mathrm{g} / \mathrm{mL})$ treatment $23 \mathrm{~h}$. Culture supernatants were measured for the production of NO using Griess assays. Andro (andrographolide) is the positive control. Data are expressed as the mean $\pm \mathrm{SD}$ from three independent experiments. Asterisk $\left.{ }^{*}\right)$ indicates significant difference versus LPS-treated vehicle control ( $p<0.05)$. The cell viability of RAW $264.7 /$ Luc-P1 cells $\left(1 \times 10^{4}\right.$ cells in 96-well plates $)(C)$ and RAW 264.7 cells $\left(1 \times 10^{4}\right.$ cells in 96-well plates) (D) incubated with sesquiterpene analogs for $24 \mathrm{~h}$ was measured using MTT assay. Data are expressed as the mean \pm SD from three independent experiments. Asterisk $\left.{ }^{*}\right)$ indicates significant difference versus vehicle control $(p<0.05)$.

It is noted that the inhibition on NO production is not always in a tight correlation with NF- $\mathrm{BB}$ activation (e.g., compounds 5, 6, and 7 in Figure 7B), which may be due to the discrepancy in experimental conditions and the sensitivity of assays used for measuring these two mediators. Alternatively, natural products are commonly known to be multiple-targeted, these compounds may be involved in NF-kB-independent NO regulation.

\section{Experimental Section}

\subsection{General Procedures}

Melting points were determined on a Yanaco micro-melting point apparatus (Yanaco, Tokyo, Japan) and were uncorrected. Optical rotations were measured using a Jasco DIP-370 polarimeter (Japan Spectroscopic Corporation, Tokyo, Japan) in $\mathrm{CHCl}_{3}$. Ultraviolet (UV) spectra were obtained on a Jasco UV-240 spectrophotometer. Infrared (IR) spectra (KBr or neat) were recorded on a Perkin Elmer 2000 FT-IR spectrometer (Perkin Elmer Corporation, Norwalk, CT, USA). Nuclear magnetic resonance (NMR) spectra, including nuclear Overhauser effect spectrometry (NOESY), correlation spectroscopy (COSY), heteronuclear single-quantum coherence (HSQC), and heteronuclear multiple-bond correlation (HMBC) experiments, were acquired using a Varian VNMRS-600 or a Varian Inova 500 spectrometer (Varian Inc., Palo Alto, CA, USA) operating at 600 or $500 \mathrm{MHz}\left({ }^{1} \mathrm{H}\right)$ and 150 or $125 \mathrm{MHz}\left({ }^{13} \mathrm{C}\right)$, respectively, with chemical shifts given in ppm $(\delta)$ using tetramethylsilane (TMS) as an internal standard. Electrospray ionisation (ESI) and high-resolution electrospray ionization (HRESI)-mass spectra were recorded on a VG Platform Electrospray ESI/MS mass spectrometer (Fison, 
Villeurbanne, France) or a Bruker APEX II (Bruker, Bremen, Germany). Silica gel (70-230, 230-400 mesh, Merck, Darmstadt, Germany) was used for column chromatography (CC). Silica gel 60 F-254 (Merck, Darmstadt, Germany) was used for preparative thin-layer chromatography (PTLC) and thin-layer chromatography (TLC).

\subsection{Plant Material}

The resinous wood of Aquilaria sinensis (Lour.) Gilg. (Thymelaeaceae) were collected from Chiayi County, Taiwan, in August 2015 and identified by J.-J. Chen. A voucher specimen (AS-201308) was deposited in the Faculty of Pharmacy, National Yang-Ming University, Taipei, Taiwan.

\subsection{Extraction and Isolation}

The dried resinous wood (600 g) of $A$. sinensis was pulverized and extracted three times with $\mathrm{MeOH}$ (15 L each) for 3 days. The extract was concentrated under reduced pressure at $35^{\circ} \mathrm{C}$, and the residue $(110 \mathrm{~g})$ was partitioned between EtOAc and $\mathrm{H}_{2} \mathrm{O}(1: 1)$ to provide the EtOAc-soluble fraction (fraction A; $65 \mathrm{~g}$ ). Fraction A (65 g) was purified by CC (3.3 kg of $\mathrm{SiO}_{2}, 70-230 \mathrm{mesh}$; $n$-hexane/acetone gradient) to afford 9 fractions: A1-A9. Fraction A1 (3.8 g) was subjected to CC (190 g of $\mathrm{SiO}_{2}$, 230-400 mesh; $n$-hexane/EtOAc 15:1-0:1, 650 mL-fractions) to give 10 subfractions: A1-1-A1-10. Part (70 mg) of fraction A1-6 was further purified by preparative TLC $\left(\mathrm{SiO}_{2} ; \mathrm{CHCl}_{3} / \mathrm{EtOAc} 60: 1\right)$ to obtain neopetasane $(5,5.2 \mathrm{mg})\left(\mathrm{R}_{f}=0.69\right)$. Part $(85 \mathrm{mg})$ of fraction A1-10 was further purified by preparative TLC $\left(\mathrm{SiO}_{2} ; \mathrm{CH}_{2} \mathrm{Cl}_{2} /\right.$ EtOAc 15:1) to afford 7 $\alpha$-H-9(10)-ene-1,12-epoxy-8-oxoeremphilane $(\mathbf{6}, 5.4 \mathrm{mg})$ $\left(\mathrm{R}_{f}=0.67\right)$. Fraction A2 (4.8 g) was subjected to CC (240 g of $\mathrm{SiO}_{2}, 230-400 \mathrm{mesh}$; $n$-hexane/EtOAc 10:1-0:1, $750 \mathrm{~mL}$-fractions) to give 10 subfractions: A2-1-A2-10. Fraction A2-2 (327 mg) was purified by $\mathrm{CC}$ (16.5 $\mathrm{g}$ of $\mathrm{SiO}_{2}, 230-400$ mesh, $\mathrm{CHCl}_{3}$ /acetone (30:1-0:1), $250 \mathrm{~mL}$-fractions) to give eight sub-fractions: A2-2-1-A2-2-8. Fraction A2-2-2 (35 mg) was further purified by preparative $\mathrm{TLC}_{(\mathrm{SiO}}$; $\mathrm{CH}_{2} \mathrm{Cl}_{2} /$ EtOAc 30:1) to yield dehydrokaranone $(7,4.1 \mathrm{mg})\left(\mathrm{R}_{f}=0.60\right)$ and 2-(2-phenylethyl)chromone $(9,4.6 \mathrm{mg})\left(\mathrm{R}_{f}=0.36\right)$. Fraction A2-8 $(235 \mathrm{mg})$ was purified by CC (11.8 $\mathrm{g}$ of $\mathrm{SiO}_{2}, 230-400$ mesh, $\mathrm{CHCl}_{3}$ /acetone (25:1-0:1), $200 \mathrm{~mL}$-fractions) to give nine subfractions: A2-8-1-A2-8-9. Fraction A2-8-4 (30 mg) was further purified by preparative TLC ( $\left.\mathrm{SiO}_{2} ; \mathrm{CH}_{2} \mathrm{Cl}_{2} / \mathrm{EtOAc} 15: 1\right)$ to afford 7-methoxy-2-(2-phenylethyl)chromone $(\mathbf{1 0}, 3.4 \mathrm{mg})\left(\mathrm{R}_{f}=0.43\right)$. Fraction A4 (7.3 g) was subjected to $\mathrm{CC}$ (365 $\mathrm{g}$ of $\mathrm{SiO}_{2}, 230-400$ mesh; $\mathrm{CH}_{2} \mathrm{Cl}_{2}$ /acetone 10:1-0:1, $800 \mathrm{~mL}$-fractions) to afford 12 subfractions: A4-1-A4-12. Part (125 mg) of fraction A4-7 was further purified by preparative TLC ( $\mathrm{SiO}_{2} ; n$-hexane/EtOAc 1:1) to yield 6,7-dimethoxy-2-(2-phenylethyl)chromone (11, $\left.5.4 \mathrm{mg}\right)$ $\left(\mathrm{R}_{f}=0.48\right)$ and ligudicin $\mathrm{C}(8,5.7 \mathrm{mg})\left(\mathrm{R}_{f}=0.35\right)$. Fraction A5 $(7.7 \mathrm{~g})$ was subjected to $\mathrm{CC}$ (385 $\mathrm{g}$ of $\mathrm{SiO}_{2}, 230-400$ mesh; $n$-hexane/EtOAc 5:1-0:1, $700 \mathrm{~mL}$-fractions) to give 11 subfractions: A5-1-A5-11. Part (110 mg) of fraction A5-6 was further purified by preparative $\mathrm{TLC}_{(\mathrm{SiO}}$; $\mathrm{CHCl}_{3}$ /acetone 20:1) to obtain 6,7-dimethoxy-2-[2-(4'-methoxyphenyl)ethyl]chromone (12, $\left.8.2 \mathrm{mg}\right)$ $\left(\mathrm{R}_{f}=0.62\right)$. Fraction A7 (7.2 g) was subjected to CC (360 g of $\mathrm{SiO}_{2}, 230-400$ mesh; $n$-hexane/acetone 4:1-0:1, $700 \mathrm{~mL}$-fractions) to give 10 subfractions: A7-1-A7-10. Fraction A7-7 (515 mg) was purified by $\mathrm{CC}$ (25.5 g of $\mathrm{SiO}_{2}, 230-400$ mesh, $\mathrm{CH}_{2} \mathrm{Cl}_{2}$ /EtOAc (10:1-0:1), 500 mL-fractions) to give eight subfractions: A7-7-1-A7-7-8. Fraction A7-7-2 (33 mg) was further purified by preparative TLC $\left(\mathrm{SiO}_{2} ; n\right.$-hexane/acetone 3:2) to obtain 7-methoxy-2-[2-(4'-hydroxy-phenyl)ethyl]chromone $(\mathbf{1}, 2.5 \mathrm{mg})\left(\mathrm{R}_{f}=0.53\right)$, 7-hydroxy-2-[2-(4'-methoxyphenyl)ethyl]chromone $(2,2.8 \mathrm{mg})\left(\mathrm{R}_{f}=0.47\right)$, and 6-hydroxy-7-methoxy-2-(2-phenylethyl)chromone (13, $3.9 \mathrm{mg})\left(\mathrm{R}_{f}=0.43\right)$. Part (95 mg) of fraction A7-9 was further purified by preparative TLC $\left(\mathrm{SiO}_{2} ; \mathrm{CH}_{2} \mathrm{Cl}_{2} / \mathrm{MeOH} 20: 1\right)$ to yield 5,6-dihydroxy-2-[2-(3'-hydroxy-4'-methoxyphenyl)ethyl]chromone $(3,3.7 \mathrm{mg})\left(\mathrm{R}_{f}=0.55\right)$. Fraction A8 (8.6 g) was subjected to $\mathrm{CC}\left(435 \mathrm{~g}\right.$ of $\mathrm{SiO}_{2}, 230-400$ mesh; hexane/acetone 2:1-0:1, $900 \mathrm{~mL}$-fractions) to afford 13 subfractions: A8-1-A8-13. Fraction A8-2 (620 mg) was purified by CC (31 g of $\mathrm{SiO}_{2}, 230-400$ mesh, $n$-hexane/EtOAc (3:1-0:1), $400 \mathrm{~mL}$-fractions) to give seven subfractions: A8-2-1-A8-2-7. Part (82 $\mathrm{mg}$ ) of fraction A8-2-6 was further purified by preparative TLC $\left(\mathrm{SiO}_{2} ; n\right.$-hexane/EtOAc $\left.1: 1\right)$ to obtain 6-hydroxy-5-methoxy-2-(2-phenylethyl)chromone $(4,4.4 \mathrm{mg})\left(\mathrm{R}_{f}=0.48\right)$. 
7-Methoxy-2-[2-(4'-hydroxyphenyl)ethyl]chromone (1): brown plates; m.p. $155-157{ }^{\circ} \mathrm{C}\left(\mathrm{CH}_{2} \mathrm{Cl}_{2}-\mathrm{MeOH}\right)$; UV (MeOH): $\lambda_{\max }(\log \varepsilon)=219$ (4.64), $247(4.41), 282(4.31), 302(4.21) \mathrm{nm}$; IR (KBr): $v_{\max }=3418(\mathrm{OH})$, 1634, 1590 ( $\gamma$-pyrone) $\mathrm{cm}^{-1} ;{ }^{1} \mathrm{H}-\mathrm{NMR}\left(\mathrm{CDCl}_{3}, 500 \mathrm{MHz}\right)$ : see Table $2 ;{ }^{13} \mathrm{C}-\mathrm{NMR}\left(\mathrm{CDCl}_{3}, 125 \mathrm{MHz}\right)$ : see Table 3; ESI-MS: $m / z=297[\mathrm{M}+\mathrm{H}]^{+}$; HR-ESI-MS: $m / z=297.11224[\mathrm{M}+\mathrm{H}]^{+}$(calcd. for $\mathrm{C}_{18} \mathrm{H}_{17} \mathrm{O}_{6}$, 297.11214).

Table 2. ${ }^{1} \mathrm{H}-\mathrm{NMR}$ data for compounds $\mathbf{1 - 4}(\delta$ in ppm, $J$ in $\mathrm{Hz})$.

\begin{tabular}{ccccc}
\hline Position & $\mathbf{1}^{\mathbf{a}}$ & $\mathbf{2}^{\mathbf{a}}$ & $\mathbf{3}^{\mathbf{a}}$ & $\mathbf{4}^{\mathbf{b}}$ \\
\hline 3 & $6.07 \mathrm{~s}$ & $6.16 \mathrm{~s}$ & $6.02 \mathrm{~s}$ & $6.06 \mathrm{~s}$ \\
5 & $8.08 \mathrm{~d}(8.5)$ & $8.02 \mathrm{~d}(9.0)$ & - & - \\
6 & $6.95 \mathrm{dd}(8.5,2.0)$ & $7.09 \mathrm{dd}(9.0,2.5)$ & - & - \\
7 & - & - & $7.28 \mathrm{~d}(9.0)$ & $7.30 \mathrm{~d}(9.3)$ \\
8 & $6.83 \mathrm{~d}(2.0)$ & $6.84 \mathrm{~d}(2.5)$ & $6.86 \mathrm{~d}(9.0)$ & $7.14 \mathrm{~d} \mathrm{(9.3)}$ \\
$2^{\prime}$ & $7.06 \mathrm{~d}(8.5)$ & $7.13 \mathrm{~d}(8.5)$ & $6.78 \mathrm{~d}(2.0)$ & $7.20 \mathrm{~d}(7.8)$ \\
$3^{\prime}$ & $6.76 \mathrm{~d}(8.5)$ & $6.83 \mathrm{~d}(8.5)$ & - & $7.30 \mathrm{t}(7.8)$ \\
$4^{\prime}$ & - & - & - & $7.22 \mathrm{t}(7.8)$ \\
$5^{\prime}$ & $6.76 \mathrm{~d}(8.5)$ & $6.83 \mathrm{~d}(8.5)$ & $6.76 \mathrm{~d}(8.0)$ & $7.30 \mathrm{t}(7.8)$ \\
$6^{\prime}$ & $7.06 \mathrm{~d}(8.5)$ & $7.13 \mathrm{~d}(8.5)$ & $6.64 \mathrm{dd}(8.0,2.0)$ & $7.20 \mathrm{~d}(7.8)$ \\
$7^{\prime}$ & $2.98 \mathrm{t}(8.0)$ & $3.05 \mathrm{t}(8.0)$ & $2.96 \mathrm{t}(7.0)$ & $3.04 \mathrm{t}(7.8)$ \\
$8^{\prime}$ & $2.86 \mathrm{t}(8.0)$ & $2.96 \mathrm{t}(8.0)$ & $2.88 \mathrm{t}(7.0)$ & $2.88 \mathrm{t}(7.8)$ \\
OH-5 & - & - & $12.50 \mathrm{~s}$ & - \\
OH-6 & - & - & $5.43 \mathrm{~s}$ & - \\
OH-3 & - & - & $5.58 \mathrm{~s}$ & - \\
OMe-5 & - & - & - & $3.98 \mathrm{~s}$ \\
$\mathrm{OMe}^{\prime} 7$ & $3.91 \mathrm{~s}$ & - & - & - \\
OMe-4 & - & 3.79 & $3.87 \mathrm{~s}$ & - \\
\hline
\end{tabular}

${ }^{\mathrm{a}}$ Measured in $\mathrm{CDCl}_{3}$ at $500 \mathrm{MHz} .{ }^{\mathrm{b}}$ Measured in $\mathrm{CDCl}_{3}$ at $600 \mathrm{MHz}$.

Table 3. ${ }^{13} \mathrm{C}-\mathrm{NMR}$ data for compounds $1-4$ ( $\delta$ in ppm).

\begin{tabular}{ccccc}
\hline Position & $\mathbf{1}^{\mathbf{a}}$ & $\mathbf{2}^{\mathbf{a}}$ & $\mathbf{3}^{\mathbf{a}}$ & $\mathbf{4}^{\mathbf{b}}$ \\
\hline 2 & 168.5 & 168.1 & 170.4 & 167.0 \\
3 & 109.8 & 110.3 & 108.2 & 110.5 \\
4 & 177.9 & 177.1 & 183.2 & 177.5 \\
5 & 127.2 & 125.2 & 145.3 & 143.5 \\
6 & 116.5 & 113.8 & 140.2 & 146.1 \\
7 & 164.1 & 156.1 & 121.6 & 120.7 \\
8 & 100.1 & 103.9 & 110.7 & 114.1 \\
9 & 158.1 & 156.6 & 144.0 & 151.4 \\
10 & 115.4 & 118.4 & 111.0 & 117.9 \\
$1^{\prime}$ & 131.5 & 131.5 & 129.5 & 139.8 \\
$2^{\prime}$ & 129.4 & 129.2 & 115.9 & 128.3 \\
$3^{\prime}$ & 115.6 & 114.1 & 144.6 & 128.7 \\
$4^{\prime}$ & 154.5 & 158.3 & 145.9 & 126.6 \\
$5^{\prime}$ & 115.6 & 114.1 & 112.0 & 128.7 \\
$6^{\prime}$ & 129.4 & 129.2 & 123.9 & 128.3 \\
$7^{\prime}$ & 32.0 & 31.9 & 30.3 & 32.9 \\
$8^{\prime}$ & 36.3 & 36.1 & 34.7 & 35.6 \\
OMe-5 $^{\prime}$ & - & - & - & 62.8 \\
OMe-7 $^{\prime}$ & 56.1 & - & - & - \\
OMe-4 $^{\prime}$ & - & 55.3 & 56.3 & -
\end{tabular}

a Measured in $\mathrm{CDCl}_{3}$ at $125 \mathrm{MHz} .{ }^{\mathrm{b}}$ Measured in $\mathrm{CDCl}_{3}$ at $150 \mathrm{MHz}$.

7-Hydroxy-2-[2-(4'-methoxyphenyl)ethyl]chromone (2): yellowish amorphous powder; UV (MeOH): $\lambda_{\max }$ $(\log \varepsilon)=222$ (4.69), 251 (4.42), $303(4.16) \mathrm{nm} ; \mathrm{IR}(\mathrm{KBr}): v_{\max }=3210(\mathrm{OH}), 1635,1600\left(\gamma\right.$-pyrone) $\mathrm{cm}^{-1}$; 
${ }^{1} \mathrm{H}-\mathrm{NMR}\left(\mathrm{CDCl}_{3}, 500 \mathrm{MHz}\right)$ : see Table 2; ${ }^{13} \mathrm{C}-\mathrm{NMR}\left(\mathrm{CDCl}_{3}, 125 \mathrm{MHz}\right)$ : see Table 3; ESI-MS: $\mathrm{m} / z=297$ $[\mathrm{M}+\mathrm{Na}]^{+}$; HR-ESI-MS: $m / z=297.11227[\mathrm{M}+\mathrm{H}]^{+}$(calcd. for $\left.\mathrm{C}_{18} \mathrm{H}_{17} \mathrm{O}_{6}: 297.11214\right)$.

5,6-Dihydroxy-2-[2-(3'-hydroxy-4'-methoxyphenyl)ethyl]chromone (3): yellowish amorphous powder; UV $(\mathrm{MeOH}): \lambda_{\max }(\log \varepsilon)=204(4.83), 235(4.52), 358(3.68) \mathrm{nm}$; IR (KBr): $v_{\max }=3418(\mathrm{OH}), 1634,1590$ ( $\gamma$-pyrone) $\mathrm{cm}^{-1} ;{ }^{1} \mathrm{H}$-NMR ( $\left.\mathrm{CDCl}_{3}, 500 \mathrm{MHz}\right)$ : see Table $2 ;{ }^{13} \mathrm{C}$-NMR $\left(\mathrm{CDCl}_{3}, 125 \mathrm{MHz}\right)$ : see Table 3; ESI-MS: $m / z=329[\mathrm{M}+\mathrm{Na}]^{+}$; HR-ESI-MS: $m / z=329.10186[\mathrm{M}+\mathrm{H}]^{+}$(calcd. for $\mathrm{C}_{18} \mathrm{H}_{17} \mathrm{O}_{6}: 329.10196$ ).

6-Hydroxy-5-methoxy-2-(2-phenylethyl)chromone (4): yellowish amorphous powder; UV (MeOH): $\lambda_{\max }$ $(\log \varepsilon)=203(4.40), 238(4.37), 334(3.71) \mathrm{nm} ; \mathrm{IR}(\mathrm{KBr}): v_{\max }=3340(\mathrm{OH}), 1633,1609\left(\gamma\right.$-pyrone) $\mathrm{cm}^{-1}$; ${ }^{1} \mathrm{H}-\mathrm{NMR}\left(\mathrm{CDCl}_{3}, 600 \mathrm{MHz}\right)$ : see Table $2 ;{ }^{13} \mathrm{C}-\mathrm{NMR}\left(\mathrm{CDCl}_{3}, 150 \mathrm{MHz}\right)$ : see Table 3; ESI-MS: $\mathrm{m} / z=319$ $[\mathrm{M}+\mathrm{Na}]^{+} ;$HR-ESI-MS: $m / z=319.09395[\mathrm{M}+\mathrm{Na}]^{+}$(calcd. for $\mathrm{C}_{18} \mathrm{H}_{16} \mathrm{O}_{4} \mathrm{Na}$ : 319.09408).

\subsection{Biological Assay}

The inhibitory effects of the isolated compounds on LPS-induced NF- $\mathrm{KB}$ activation in RAW 264.7/Luc-P1 macrophage were evaluated by measuring the luminescence resulted from luciferase activity in a concentration-dependent manner. The purity of the tested compounds was $>98 \%$ as identified by NMR and MS.

\subsubsection{Cells and Culture Medium}

RAW 264.7/Luc-P1 cell was an LPS-responsive cell line with an integrated reporter gene (pELAM1-Luc). The cell line was cultured under conditions as described previously [10]. The RAW 264.7/Luc-P1 cells were regularly cultured at $37^{\circ} \mathrm{C}$ in $5 \% \mathrm{CO}_{2}$ incubator in DMEM supplemented with $10 \%$ heat-inactivated $\mathrm{BCS}, 100 \mathrm{U} / \mathrm{mL}$ penicillin, $100 \mu \mathrm{g} / \mathrm{mL}$ streptomycin, $2 \mu \mathrm{M}$ L-glutamine, and $1 \mathrm{mM}$ sodium pyruvate.

\subsubsection{Luciferase Reporter Assay}

The RAW 264.7/Luc-P1 cells $\left(1.5 \times 10^{5}\right.$ cells in 24-well plates) were treated with isolated compounds, vehicle (0.1\% DMSO) or the positive control $(30 \mu \mathrm{M}$ andrographolide) for $1 \mathrm{~h}$ and then LPS $(10 \mathrm{ng} / \mathrm{mL})$ for $23 \mathrm{~h}$, collected, and analyzed using luciferase assays (Promega, Madison, WI, USA). Cell lysates $(20 \mu \mathrm{L})$ were then mixed with $100 \mu \mathrm{L}$ luciferin right before luminescence detection [11]. The luminescence was measured with an Infinite ${ }^{\circledR} 200$ PRO (Tecan Group Ltd., Männedorf, Switzerland).

\subsubsection{Cytotoxicity Assay}

The MTT assay was used according to a previously described method [21]. RAW 264.7 cells or RAW 264.7/Luc-P1 cells $\left(1 \times 10^{4}\right.$ cells $)$ were seeded into 96-well plates and treated with compounds $(3,5-7$, and $10-12)$ and $0.1 \%$ DMSO for $24 \mathrm{~h}$.

\subsubsection{Determination of Nitric Oxide (NO) Production}

RAW 264.7 cells $\left(4 \times 10^{4}\right.$ cells) were seeded into 96-well plates and treated with compounds (3, 5-7, and 10-12) and 0.1\% DMSO for $1 \mathrm{~h}$, then incubated with LPS $(1 \mu \mathrm{g} / \mathrm{mL})$ for $23 \mathrm{~h}$. The $100 \mu \mathrm{L}$ of cell culture medium was incubated with $100 \mu \mathrm{L}$ of Griess reagent at room temperature for $10 \mathrm{~min}$. The absorbance was measured at $550 \mathrm{~nm}$ against a calibration curve with sodium nitrite $\left(\mathrm{NaNO}_{2}\right)$ standards.

\subsubsection{Statistical Analysis}

Data are shown as mean \pm SD of three independent experiments. Statistical analysis was performed using ANOVA followed by post hoc Dunnett's test to compare between-group differences. Differences were considered as statistically significant when $p<0.05$. 


\section{Conclusions}

Thirteen compounds, including four new 2-(2-phenylethyl)-4H-chromen-4-one derivatives 1-4 were isolated from the resinous wood of $A$. sinensis. The structures of these compounds were established on the basis of spectroscopic data. The activity assays revealed that compounds 3 , 5-7, and 10-12 inhibited LPS-stimulated NF- $\mathrm{kB}$ activation with relative luciferase activity values of $0.74 \pm 0.03,0.55 \pm 0.09,0.75 \pm 0.05,0.72 \pm 0.10,0.54 \pm 0.03,0.31 \pm 0.05$, and $0.38 \pm 0.14$, respectively. Moreover, chromone derivatives could suppress LPS-induced NO production without causing significant cytotoxicity. Our study suggests that agarwood and its isolates (especially compound 11) are worthy of further biomedical investigation and could be developed as potential candidates for the treatment or prevention of various inflammatory diseases. The structure-and-activity relationship (SAR) of these isolated compounds in term of anti-inflammatory activity certainly merits further investigation.

Supplementary Materials: Supplementary materials are available online, Figures S1-S8: MS, 1D, and 2D-NMR spectra for 7-methoxy-2-[2-(4'-hydroxyphenyl)ethyl]chromone (1), Figures S9-S16: MS, 1D, and 2D-NMR spectra for 7-hydroxy-2-[2-(4'-methoxyphenyl)ethyl]chromone (2), Figures S17-S24: MS, 1D, and 2D-NMR spectra for 5,6-dihydroxy-2-[2-(3'-hydroxy-4'-methoxyphenyl)ethyl]chromone (3), Figures S25-S32: MS, 1D, and 2D-NMR spectra for 6-hydroxy-5-methoxy-2-(2-phenylethyl)chromone (4).

Acknowledgments: This research was supported by grants from the Ministry of Science and Technology, Taiwan (No. MOST 106-2320-B-010-033-MY3 and MOST 103-2320-B-010-007-MY3), awarded to Jih-Jung Chen and Shu-Ling Fu.

Author Contributions: Sin-Ling Wang performed the isolation and structure elucidation of the constituents, and manuscript writing. Yun-Chen Tsai, Shu-Ling Fu, and Ming-Jen Cheng conducted the bioassay and analyzed the data. Jih-Jung Chen and Mei-Ing Chung planned, designed, and organized all of the research of this study and the preparation of the manuscript. All authors read and approved the final version of the manuscript.

Conflicts of Interest: The authors declare no conflict of interest.

\section{References}

1. National Pharmacopoeia Commission. Pharmacopoeia of the People's Republic of China; China Medical Science and Technology Press: Beijing, China, 2010; pp. 172-173.

2. Wang, S.L.; Hwang, T.L.; Chung, M.I.; Sung, P.J.; Shu, C.W.; Cheng, M.J.; Chen, J.J. New flavones, a 2-(2-phenylethyl)-4H-chromen-4-one derivative, and anti-inflammatory constituents from the stem barks of Aquilaria sinensis. Molecules 2015, 20, 20912-20925. [CrossRef] [PubMed]

3. Wang, H.G.; Zhou, M.H.; Lu, J.J.; Yu, B.Y. Antitumor constituents from the leaves of Aquilaria sinensis (Lour.) Gilg. Linchan Huaxue Yu Gongye 2008, 28, 1-5.

4. Yang, J.S.; Wang, Y.L.; Su, Y.L. Studies on the chemical constituents of Aquilaria sinensis (Lour.) Gilg. IV. Isolation and characterization of 2-(2-phenylethyl)chromone derivatives. Yaoxue Xuebao 1989, 24, 678-683.

5. Lin, L.D.; Qi, S.Y. Triterpenoid from Chinese eaglewood (Aquilaria sinensis). Zhongcaoyao 2000, 31, 89-90.

6. Liu, J.; Wu, J.; Zhao, Y.X.; Deng, Y.Y.; Mei, W.L.; Dai, H.F. A new cytotoxic 2-(2-phenylethyl)chromone from Chinese eaglewood. Chin. Chem. Lett. 2008, 19, 934-936. [CrossRef]

7. Chen, D.; Xu, Z.; Chai, Z.; Zeng, K.; Jia, Y.; Bi, D.; Ma, Z.; Tu, P. Nine 2-(2-phenylethyl)chromone derivatives from the resinous wood of Aquilaria sinensis and their inhibition of LPS-induced NO production in RAW 264.7 cells. Eur. J. Org. Chem. 2012, 27, 5389-5397. [CrossRef]

8. Yang, D.L.; Wang, H.; Guo, Z.K.; Li, W.; Mei, W.L.; Dai, H.F. Fragrant agarofuran and eremophilane sesquiterpenes in agarwood 'Qi-Nan' from Aquilaria sinensis. Phytochem. Lett. 2014, 8, 121-125. [CrossRef]

9. Jou, I.M.; Lin, C.F.; Tsai, K.J.; Wei, S.J. Macrophage-mediated inflammatory disorders. Mediat. Inflamm. 2013, 2013, 316482. [CrossRef] [PubMed]

10. Fu, S.L.; Hsu, Y.H.; Lee, P.Y.; Hou, W.C.; Hung, L.C.; Lin, C.H.; Chen, C.M.; Huang, Y.J. Dioscorin isolated from Dioscorea alata activates TLR4-signaling pathways and induces cytokine expression in macrophages. Biochem. Biophys. Res. Commun. 2006, 339, 137-144. [CrossRef] [PubMed]

11. Tsai, Y.C.; Chen, S.H.; Lin, L.C.; Fu, S.L. Anti-inflammatory principles from Sarcandra glabra. J. Agric. Food Chem. 2017, 65, 6497-6505. [CrossRef] [PubMed] 
12. Shimada, Y.; Tominaga, T.; Konishi, T.; Kiyosawa, S. Studies on the agarwood (Jinko). I. Structures of 2-(2-phenylethyl)chromone derivatives. Chem. Pharm. Bull. 1982, 30, 3791-3795. [CrossRef]

13. Xia, F.; Sun, J.; Jiang, Y.; Tu, P.F. Further chemical investigation of leaves of Aquilaria Sinensis. Zhongguo Zhongyao Zazhi 2013, 38, 3299-3303. [PubMed]

14. Riclea, R.; Dickschat, J.S. Identification of intermediates in the biosynthesis of PR toxin by Penicillium roqueforti. Angew. Chem. Int. Ed. 2015, 54, 12167-12170. [CrossRef] [PubMed]

15. Hashimoto, K.; Nakahara, S.; Inoue, T.; Sumida, Y.; Takahashi, M.; Masada, Y. A new chromone from agarwood and pyrolysis products of chromone derivatives. Chem. Pharm. Bull. 1985, 33, 5088-5091. [CrossRef]

16. Ismail, K.A.; Abd El Aziem, T. Synthesis and biological evaluation of some novel 4H-benzopyran-4-one derivatives as nonsteroidal antiestrogens. Eur. J. Med. Chem. 2001, 36, 243-253. [CrossRef]

17. Iwagoe, K.; Konishi, T.; Kiyosawa, S.; Shimada, Y.; Miyahara, K.; Kawasaki, T. Studies on the agarwood (Jinko). VII. Structures of phenylethylchromone derivatives $\mathrm{AH}_{7}, \mathrm{AH}_{8}$ and $\mathrm{AH}_{9}$. Chem. Pharm. Bull. 1988, 36, 2417-2422. [CrossRef]

18. Konishi, T.; Konoshima, T.; Shimada, Y.; Kiyosawa, S. Six new 2-(2-phenylethyl)chromones from agarwood. Chem. Pharm. Bull. 2002, 50, 419-422. [CrossRef] [PubMed]

19. Liu, S.H.; Lin, C.H.; Hung, S.K.; Chou, J.H.; Chi, C.W.; Fu, S.L. Fisetin inhibits lipopolysaccharide-induced macrophage activation and dendritic cell maturation. J. Agric. Food Chem. 2010, 58, 10831-10839. [CrossRef] [PubMed]

20. MacMicking, J.; Xie, Q.W.; Nathan, C. Nitric oxide and macrophage function. Annu. Rev. Immunol. 1997, 15, 323-350. [CrossRef] [PubMed]

21. Socolsky, C.; Plietker, B. Total synthesis and absolute configuration assignment of MRSA active garcinol and isogarcinol. Chem.-Eur. J. 2015, 21, 3053-3061. [CrossRef] [PubMed]

Sample Availability: Samples of the compounds are available from the authors.

(C) 2018 by the authors. Licensee MDPI, Basel, Switzerland. This article is an open access article distributed under the terms and conditions of the Creative Commons Attribution (CC BY) license (http://creativecommons.org/licenses/by/4.0/). 